\title{
URINE OCHRATOXIN A AND SPHINGANINE/ SPHINGOSINE RATIO IN RESIDENTS OF THE ENDEMIC NEPHROPATHY AREA IN CROATIA*
}

\author{
Ana-Marija DOMIJAN ${ }^{1}$, Maja PERAICA ${ }^{1}$, Ksenija MARKOV ${ }^{2}$, and Radovan FUCHS ${ }^{1}$, \\ Institute for Medical Research and Occupational Health, Zagreb ${ }^{1}$, Faculty of Food Technology and Biotechnology, \\ University of Zagreb², Zagreb, Croatia
}

Received in January 2009

Accepted in May 2009

\begin{abstract}
The most plausible theory of the aetiology of endemic nephropathy links it with exposure to nephrotoxic mycotoxin ochratoxin A (OTA). In this study, the concentration of OTA and sphinganine/sphingosine $(\mathrm{Sa} / \mathrm{So})$ ratio, the biomarker of another nephrotoxic mycotoxin fumonisin $\mathrm{B}_{1}$ exposure, were analysed in 45 human urine samples collected in the endemic village of Kaniža in Croatia and in 18 samples from control village. Samples were collected twice from the same persons in 2000 and 2005. In both years the frequency of OTA-positive samples was higher in Kaniža ( $43 \%$ and $18 \%$, respectively) than in the control village ( $28 \%$ and $6 \%$, respectively). OTA concentrations in samples collected in Kaniža were higher in 2000 than in $2005(\mathrm{p}<0.005)$. Although in both years Sa/So ratio was higher in Kaniža, the difference from the control group was not statistically significant. No control sample contained OTA and had the Sa/So ratio $>1$ at the same time, while in Kaniža four such samples were collected in 2000 and one in 2005.
\end{abstract}

KEY WORDS: endemic nephropathy, fumonisin $B_{l}, H P L C$, ochratoxin A, sphingolipids

Endemic nephropathy (EN) is a fatal human kidney disease that occurs in 14 villages in the eastern part of the Croatian Brodsko-posavska county. In the 1970s, the aetiology of the disease was believed to be related to exposure to mycotoxin ochratoxin A (OTA) (1). High incidence of otherwise rare urothelial tumours observed later in the same endemic region was also associated with this toxin $(2,3)$. Studies on laboratory and domestic animals have shown that OTA is nephrotoxic, carcinogenic, genotoxic, and immunotoxic (4). The International Agency for Research on Cancer (IARC) has classified OTA as Group 2B carcinogens (possible human carcinogen)

\footnotetext{
" The manuscript was presented at the $2^{\text {nd }}$ Croatian Scientific Symposium with International Participation Fungi and Mycotoxins - Health Aspects and Prevention, held in Zagreb, Croatia on 5 December 2008.
}

(5). OTA was found in various commodities from endemic villages (6), and its concentration was much higher in maize collected in the endemic than in control regions in the 1997 crop (7). The same difference was observed by Puntarić et al. (8) for wheat and maize samples collected in 1999. Although OTA was more frequent in the plasma of the residents of endemic villages, it was also found in the plasma of the residents of control villages (9). Low concentrations of OTA are frequent in the healthy population of Croatia and other countries where EN is not known (10).

Some earlier studies on maize contamination with mycotoxins in the endemic region and the whole of Croatia revealed a high percentage of samples contaminated with fumonisins and to a lesser extent with OTA $(7,11)$. The most frequent fumonisin in 
maize was fumonisin $\mathrm{B}_{1}\left(\mathrm{FB}_{1}\right)$. In some regions of Africa and China unusually frequent oesophageal cancer and primary liver cancer in humans was associated with high exposure to $\mathrm{FB}_{1}$. IARC classified $\mathrm{FB}_{1}$ in the same group of carcinogens as OTA (Group 2B) (12). Animal studies have shown that $\mathrm{FB}_{1}$ is poorly absorbed and rapidly distributed and eliminated. This makes $\mathrm{FB}_{1}$ measurement in biological materials useless for evaluation of exposure to this mycotoxin. However, it is established that $\mathrm{FB}_{1}$ toxicity is the consequence of the inhibition of ceramide synthase, a key enzyme in the biosynthesis of sphigolipids. Animal studies have shown that an elevated ratio of sphingolipids sphinganine and sphingosine $(\mathrm{Sa} / \mathrm{So})$ is a reliable biomarker of exposure to fumonisins. This marker had already been evaluated in the serum and urine of subjects living in the EN region (13), and the study showed higher Sa and So concentrations, and higher $\mathrm{Sa} / \mathrm{So}$ ratio in residents of the endemic region.

The geographically limited occurrence of EN and particular urothelial tumours suggest that some other natural contaminant could add to OTA toxicity and contribute to the development of EN. Since earlier exposure data for the residents of the endemic villages are separate for OTA and fumonisins (Sa/So ratio), the aim of this study was to see whether exposure to these two mycotoxins was in fact combined. The same subjects were tested for these two mycotoxins in 2000 and 2005 to accommodate for high variability of grain contamination from year to year.

\section{MATERIALS AND METHODS}

\section{Chemicals}

Standards of OTA, sphingoid bases $\left(\mathrm{C}_{18}\right.$-Dsphingosine and $\mathrm{C}_{18}$-DL-erythro-dihydrosphingosine), $o$-phthaldialdehyde (OPA), and 2-mercaptoethanol were purchased from Sigma (St. Louis, MO, USA). Water for HPLC mobile phase and silica gel Si-60 (15 $\mu \mathrm{m}$ to $40 \mu \mathrm{m}$ ) were obtained from Merck (Darmstadt, Germany). Methanol, acetic acid, hydrochloric acid, chloroform, sodium sulphate anhydrous crystal, and formic acid were supplied by Kemika (Zagreb, Croatia). All chemicals were of pro-analysis grade. Water and methanol used for HPLC mobile phase were of HPLC grade.

\section{Urine samples}

For OTA and sphingolipid analysis, spot human urine samples were collected from 63 subjects in the spring of 2000 and 2005 , and kept frozen at $-80{ }^{\circ} \mathrm{C}$ until analysis. Forty-five samples were from the endemic village of Kaniža and 18 from a control village where $\mathrm{EN}$ is not known. Urine was sampled according to the Croatian law, with the previous approval of the Ethics Committee of the Institute for Medical Research and Occupational Health in Zagreb.

\section{HPLC system}

The high-performance liquid chromatograph used in the experiment consisted of a gradient pump (INERT 9012, Varian, Walnut-Creek, CA, USA), manual injector (Rheodyne 7125, Cotati, CA, USA) with a $50 \mu \mathrm{L}$ loop, and a fluorescent detector (9075, Varian, Walnut-Creek, CA, USA). The guard column and analytical column were LiChrospher RP-18 (Merck, Darmstadt, Germany) with $5 \mu \mathrm{m}$ particles and their size was $4 \mathrm{~mm} \times 4 \mathrm{~mm}$ and $125 \mathrm{~mm} \times 4 \mathrm{~mm}$, respectively. Chromatographic data were collected and processed using Star Chromatography Workstation software (Ver. 5.0, Varian, Walnut-Creek, CA, USA). The analysis was performed at room temperature.

\section{Determination of OTA}

To determine OTA concentrations in the urine we adopted the method of Pascale and Visconti (14). This method uses immunoaffinity columns (OchraTest ${ }^{\mathrm{TM}}$, Vicam, Watertown, MA, USA) for sample cleanup procedure. Urine samples $(10.0 \mathrm{~mL})$ were diluted with $5 \% \mathrm{NaHCO}_{3}(10.0 \mathrm{~mL})$, mixed, and filtered through Whatman No.1 filter paper. Ten $\mathrm{mL}$ of filtered sample were transferred to OchraTest ${ }^{\mathrm{TM}}$ immunoaffinity columns. Immunoaffinity columns were washed twice with distilled water $(5.0 \mathrm{~mL})$, and OTA was eluted with $2 \mathrm{~mL}$ methanol. The eluted extract was evaporated under a stream of nitrogen in a water bath at $60{ }^{\circ} \mathrm{C}$. The residues were kept at $+4{ }^{\circ} \mathrm{C}$ until analysis. Just before HPLC analysis, the residues were dissolved in $300 \mu \mathrm{L}$ of the mobile phase.

For OTA analysis, the mobile phase consisted of methanol, water, and acetic acid (70:30:2), and the flow-rate was $0.5 \mathrm{~mL} \mathrm{~min}^{-1}$. The excitation wavelength of the fluorescence detector was set at $336 \mathrm{~nm}$, and the emission wavelength was $464 \mathrm{~nm}$. Validation of the method showed linear standard curve $\left(\mathrm{r}^{2}=0.998\right)$. OTA detection limit of the method was $0.005 \mathrm{ng} \mathrm{mL}^{-1}$ and reproducibility (day to day precision), expressed 
as relative standard deviation (RSD), was $3.5 \%$. The presence of OTA in some OTA-positive samples was confirmed by adding OTA standard to the sample.

\section{Determination of sphingolipids}

Free So and Sa concentrations in the urine samples were determined using the method of Solfrizzo et al. (15). Urine $(2.0 \mathrm{~mL})$ was diluted with methanol $(1.9 \mathrm{~mL})$, alkalinised with $1.2 \mathrm{~mL} \mathrm{NH}_{4} \mathrm{OH}(0.35 \mathrm{~mol}$ $\left.\mathrm{L}^{-1}\right)$, and extracted with chloroform $(4.0 \mathrm{~mL})$. After centrifugation, the chloroform extract was cleaned up through a silica gel mini-column consisting of $5.0 \mathrm{~g}$ of sodium sulphate anhydrous crystal packed on top of $0.2 \mathrm{~g}$ silica gel 60 . The mini-column was conditioned with chloroform and then loaded with the sample. So and Sa were eluted from the mini-column with $4 \mathrm{~mL}$ of $\mathrm{CHCl}_{3}: \mathrm{MeOH}: \mathrm{NH}_{4} \mathrm{OH}$ (50:50:2). The collected eluate was evaporated to dryness in a water bath under a stream of nitrogen at $60{ }^{\circ} \mathrm{C}$. Before injection, the sample was redissolved in $250 \mu \mathrm{L}$ of methanol, and derivatised in reaction with $50 \mu \mathrm{L}$ of o-phthaldialdehyde (OPA).

The mobile phase consisted of methanol and water (90:10). The flow rate was $1.0 \mathrm{~mL} \mathrm{~min}{ }^{-1}$. Wavelengths of the detector were set at $\lambda_{\mathrm{em}} 334 \mathrm{~nm}$ and $\lambda_{\mathrm{ex}} 440 \mathrm{~nm}$. Validation of the method showed linear standard curves for So and $\mathrm{Sa}$ (with $\mathrm{r}^{2}=0.997$ and $\mathrm{r}^{2}=0.996$, respectively). The detection limit for sphingolipids was $0.1 \mathrm{ng} \mathrm{mL}^{-1}$ and RSD below $10 \%$.

\section{Statistics}

Differences in the means of two independent samples between the groups were evaluated with the Student's $t$-test using Statistica 5.0. Probability values of $p<0.05$ were considered statistically significant.

\section{RESULTS}

Tables 1 and 2 show urine OTA concentrations and $\mathrm{Sa} / \mathrm{So}$ ratio measured in samples collected from 45 residents of the endemic village of Kaniža and 18 control subjects in 2000 and 2005. In both years the mean OTA concentration in positive samples was higher in Kaniža than in control samples. Mean OTA concentration in all samples collected in Kaniža in 2000 was higher than in $2005(\mathrm{p}<0.005)$.

In both years the frequency of OTA-positive samples was also higher in Kaniža residents than controls. In addition, it was higher in 2000 than in 2005 in both groups of subjects.
Mean Sa/So ratio was higher in the urine collected from Kaniža residents than from controls in both years (Table 2). No control urine sample had the Sa/So ratio $>1.0$. The number of samples from Kaniža with $\mathrm{Sa} / \mathrm{So}$ ratio >1.0 was higher in 2000 than in 2005 . Four samples collected from Kaniža in 2000 and one in 2005 contained both detectable amounts of OTA and $\mathrm{Sa} / \mathrm{So}$ ratio $>1$.

\section{DISCUSSION}

Mycotoxins are still the most plausible cause of EN development. EN's geographically limited occurrence in Croatia and other countries suggests that its aetiology should involve a local natural toxin. The most common suspect is OTA, which was found more frequently in the plasma of endemic region residents than in controls (9). As OTA is excreted via urine, positive urine finding is used to confirm human exposure to this mycotoxin $(14,16,17)$.

In our study, OTA-positive samples were found in both subject groups and in both years of sampling. This result is not surprising because we had already found OTA in the plasma of healthy Croatian population who did not live in the endemic area (10). However, the frequency of positive samples was higher in the residents of the endemic village of Kaniža than in the control village, which corroborates the study by Radić et al. (9). This could be the consequence of higher OTA contamination of cereals in the endemic than in other areas $(7,8)$.

It is interesting to note that the higher mean concentration of OTA and higher percentage of OTApositive urine samples was found in 2000 than in 2005 regardless of the sampling location. The urine samples were collected in the spring, when the subjects still consumed last year's crop. According to the data of the Meteorological and Hydrological Service of Croatia, the years preceding urine sampling were climatically very different. In 1999, the temperature and rainfall in the EN area significantly exceeded the long term average, while in 2004, both parameters were only slightly above the normal (18). In the endemic area of Croatia, significant year-to-year variability of OTA concentration has already been observed for maize (7).

In our study of maize collected in 14 counties of Croatia, $\mathrm{FB}_{1}$ concentration was above the detection limit in all samples (11). A similar very high frequency of $\mathrm{FB}_{1}$-positive samples was found in maize collected 
Table 1 Mean OTA concentrations in urine samples and the frequency of positive samples in 2000 and 2005

\begin{tabular}{|c|c|c|c|c|c|c|c|}
\hline \multirow{3}{*}{ Year } & \multirow{3}{*}{ Samples } & \multirow{3}{*}{$\mathbf{N}$} & \multirow{3}{*}{ n } & All samples & Posi & samples & \multirow{3}{*}{$\begin{array}{c}\text { Frequency } \\
\text { of positive } \\
\text { samples } / \%\end{array}$} \\
\hline & & & & \multicolumn{3}{|c|}{ Mass concentration of OTA / $\mathrm{ng} \mathrm{mL}^{-1}$} & \\
\hline & & & & \multicolumn{2}{|c|}{ Mean \pm SD } & Range & \\
\hline \multirow{2}{*}{2000} & Controls & 18 & 5 & $0.003 \pm 0.005$ & $0.01 \pm 0.006$ & 0.005 to 0.02 & 28 \\
\hline & Kaniža & 45 & 19 & $0.007 \pm 0.014$ & $0.017 \pm 0.018$ & 0.005 to 0.086 & 43 \\
\hline \multirow{2}{*}{2005} & Controls & 18 & 1 & $0.005 \pm 0.024$ & 0.01 & 0.01 & 6 \\
\hline & Kaniža & 45 & 8 & $0.001 \pm 0.003^{* *}$ & $0.007 \pm 0.003$ & 0.005 to 0.015 & 18 \\
\hline
\end{tabular}

$N$ - number of samples

$n$-number of positive samples

** different from concentration in Kaniža in $2000(p<0.005)$

Table 2 Mean sphingosine (Sa) and sphinganine (So) concentrations, Sa/So ratios, and the frequency of samples with Sa/So ratio below and above 1.0 in 2000 and 2005

\begin{tabular}{|c|c|c|c|c|c|c|c|c|c|}
\hline \multirow{3}{*}{ Year } & \multirow{3}{*}{ Samples } & \multirow{3}{*}{$\mathbf{N}$} & Sphingosine & Sphinganine & \multirow{3}{*}{$\begin{array}{c}\text { Sa/So } \\
\text { ratio }\end{array}$} & \multirow{3}{*}{\multicolumn{2}{|c|}{$\begin{array}{c}\mathrm{Sa} / \mathrm{So}<1 \\
\begin{array}{c}\text { Frequency } \\
\text { of samples/ } \\
\%\end{array}\end{array}$}} & \multirow{3}{*}{\multicolumn{2}{|c|}{$\begin{array}{c}\text { Sa/So }>1 \\
\begin{array}{c}\text { Frequency } \\
\text { of samples } \\
\%\end{array}\end{array}$}} \\
\hline & & & \multicolumn{2}{|c|}{ Mass concentration / $\mathrm{ng} \mathrm{mL}^{-1}$} & & & & & \\
\hline & & & & Mean \pm SD & & & & & \\
\hline \multirow{2}{*}{2000} & Controls & 18 & $3.72 \pm 2.83$ & $0.79 \pm 0.75$ & $0.19 \pm 0.09$ & 18 & 100 & - & - \\
\hline & Kaniža & 45 & $2.54 \pm 2.95$ & $2.47 \pm 2.90$ & $1.79 \pm 1.98$ & 33 & 73 & 12 & 27 \\
\hline \multirow{2}{*}{2005} & Controls & 18 & $5.84 \pm 8.05$ & $1.78 \pm 2.86$ & $0.33 \pm 0.27$ & 18 & 100 & - & - \\
\hline & Kaniža & 45 & $0.93 \pm 0.46$ & $2.38 \pm 9.34$ & $1.45 \pm 4.44$ & 43 & 96 & 2 & 4 \\
\hline
\end{tabular}

$N$ - number of samples

$n$-number of positive samples

both from the endemic and non-endemic areas (7). In the only Croatian study of urine $\mathrm{Sa} / \mathrm{So}$ ratio performed by now, this ratio was significantly higher in persons with suspected EN and in healthy subjects from the endemic area than in controls, regardless of the sex (13). In our study, mean urine $\mathrm{Sa} /$ So ratio was also higher in Kaniža residents than in controls, but due to the high variability of data, this difference is not statistically significant (Table 2). Although the endemic area is not known for high consumption of maize, mean $\mathrm{Sa} / \mathrm{So}$ ratio in the urine collected in 2000 and 2005 in Kaniža was similar or higher (1.79 and 1.45 , respectively) than in the urine of persons living in the areas of North Argentina and South Brazil known for high consumption of maize $(0.69$ and 1.57 , respectively) (19). Control values for $\mathrm{Sa} / \mathrm{So}$ in our study in 2000 and 2005 were 0.19 and 0.33 , respectively, which is in accordance with the $\mathrm{Sa} / \mathrm{So}$ ratios from earlier studies ranging from 0.12 to 0.43 $(13,19-21)$.
It is known that $\mathrm{FB}_{1}$ significantly increases $\mathrm{Sa}$ and to a lesser extent So concentration in experimental animals. This discrepancy reflects in changed $\mathrm{Sa} / \mathrm{So}$ ratio. Studies of humans consuming home-grown maize contaminated with fumonisins showed no increase in the $\mathrm{Sa} / \mathrm{So}$ ratio (19). It seems that change in the $\mathrm{Sa} / \mathrm{So}$ ratio is not sensitive enough to be a biomarker of fumonisin exposure in humans, probably because humans are exposed to a much lower level of fumonisins than experimental animals. The arbitrary $\mathrm{Sa} / \mathrm{So}$ ratio cut off of above 1.0 shows that $\mathrm{Sa}$ is higher than So, which in turn suggests exposure to fumonisins. When we set the cut off for $\mathrm{Sa} / \mathrm{So}$ ratio to 1.0 (see 19), we found that all samples $>1.0$ originated from Kaniža (Table 2).

Although the co-occurrence of OTA and FB in maize seems to be quite frequent in Croatia $(7,11)$, only five samples in our study, all of them collected in Kaniža, indicated the exposure to both mycotoxins. This is probably because these mycotoxins are 
produced by different moulds (mostly Penicillium spp. and Fusarium spp., respectively). Human exposure to these two mycotoxins is particularly interesting not only because of additive and even synergistic effect on cultured cells $(22,23)$ but also because of the synergistic increase in DNA lesions seen in the kidney of experimental animals treated with both mycotoxins (24). Despite the well-known nephrotoxicity and carcinogenicity of $\mathrm{OTA}_{\mathrm{A}}$ and $\mathrm{FB}_{1}$ in vitro and in animal studies, nothing is known about their effect in humans. This is the first report on combined human exposure to these two mycotoxins. Our results have confirmed that human exposure to OTA and $\mathrm{FB}_{1}$ varies from year to year. Higher frequency of OTA-positive samples and the higher number of samples with $\mathrm{Sa} / \mathrm{So}$ ratio $>1.0$ in the endemic than in the control village call for a continued study of this issue.

\section{Acknowledgements}

We wish to thank Mrs Mirjana Matašin for technical assistance. This study was supported by the Ministry of Science, Education and Sports of the Republic of Croatia (grant No 0022-0222148-2142).

\section{REFERENCES}

1. Krogh P. Mycotoxic porcine nephropathy: a possible model for Balkan endemic nephropathy. In: Puchlev E, editor. Endemic Nephropathy. Proceedings of the $2^{\text {nd }}$ International Symposium on Endemic Nephropathy; 9-11 Nov 1972; Sofia, Boulgaria. Sofia: Publishing House of Bulgarian Academy of Sciences; 1974. p. 266-70.

2. Čeović S, Pleština R, Miletić-Medved M, Stavljenić A, Mitar J, Vukelić M. Epidemiological aspects of Balkan endemic nephropathy in a typical focus in Yugoslavia. In: Castegnaro M, Pleština R, Dirheimer G, Chernozemsky IN, Bartsch H, editors. Mycotoxins, endemic nephropathy and urinary tract tumours. Lyon: IARC; 1991. p. 5-10.

3. Miletić-Medved M, Domijan A-M, Peraica M. Recent data on endemic nephropathy and related urothelial tumors in Croatia. Wien Klin Wochen 2005;117:604-9.

4. International Programme on Chemical Safety (IPCS). Safety evaluation of certain mycotoxins in food. WHO Food Additives Series, Vol. 47. Geneva: WHO/FAO; 2001.

5. International Agency for Research on Cancer (IARC). Some naturally occurring substances: food items and constituents, heterocyclic aromatic amines and mycotoxins. IARC Monographs on the Evaluation of Carcinogenic Risks to Humans, Vol. 56. Lyon: IARC/WHO; 1993.

6. Pavlović M, Pleština R, Krogh P. Ochratoxin A contamination of foodstuffs in an area with Balkan (endemic) nephropathy. Acta Pathol Microbiol Scand Sect B 1979;87:243-6.

7. Jurjević Ž, Solfrizzo M, Cvjetković B, Avantaggiato G, Visconti A. Ochratoxin $\mathrm{A}$ and fumonisins $\left(\mathrm{B}_{1}\right.$ and $\left.\mathrm{B}_{2}\right)$ in maize form Balkan nephropathy endemic and non endemic areas of Croatia. Mycotoxins Res 1999;15:67-80.

8. Puntarić D, Bošnir J, Šmit Z, Škes I, Baklaić Z. Ochratoxin $A$ in corn and wheat: geographical association with endemic nephropathy. Croat Med J 2001;42:175-80.

9. Radić B, Fuchs R, Peraica M, Lucić A. Ochratoxin A in human sera in the area with endemic nephropathy in Croatia. Toxicol Lett 1997;91:105-9.

10. Peraica M, Domijan A-M, Fuchs R, Lucić A, Radić, B. The occurrence of ochratoxin A in blood in general population of Croatia. Toxicol Lett 1999;110:105-12.

11. Domijan A-M, Peraica M, Jurjević Ž, Ivić D, Cvjetković B. Fumonisin $\mathrm{B}_{1}$, fumonisin $\mathrm{B}_{2}$, zearalenone and ochratoxin A contamination of maize in Croatia. Food Addit Contam 2005;22:677-80.

12. International Agency for Research on Cancer (IARC). Some traditional herbal medicines, some mycotoxins, naphthalene and styrene. IARC Monographs on the Evaluation of Carcinogenic Risks to Humans, Vol. 82. Lyon: IARC; 2002.

13. Ribar S, Mesarić M, Bauman M. High-performance liquid chromatographic determination of sphinganine and sphingosine in serum and urine of subjects from an endemic nephropathy area in Croatia. J Chromatogr B 2001;754:5119.

14. Pascale M, Visconti A. Rapid method for the determination of ochratoxin A in urine by immunoaffinity column clean-up and high-performance liquid chromatography. Mycopathologia 2000;152:91-5.

15. Solfrizzo M, Avantagiato G, Visconti A. Rapid method to determine sphinganine/sphingosine in human and animal urine as a biomarker for fumonisin exposure. J Chromatogr B Biomed Sci Appl1997;692:87-93.

16. Fazekas B, Tar A, Kovacs M. Ochratoxin A content of urine samples of healthy humans in Hungary. Acta Vet Hung 2005;53:35-44.

17. Pena A, Seifrtova M, Lino C, Silveira I, Solich P. Estimation of ochratoxin A in Portuguese population: New data on the occurrence in human urine by high performance liquid chromatography with fluorescence detection. Food Chem Toxicol 2006;44:1449-54.

18. Meteorological and Hydrological Service of Croatia [displayed 11 May 2009]. Available at http://www.meteo. hr.

19. Solfrizzo M, Chulze SN, Mallmann C, Visconti A, De Girolamo A, Rojo F, Torres A. Comparison of urinary sphingolipids in human populations with high and low maize consumption as a possible biomarker of fumonisin dietary exposure. Food Addit Contam 2004;21:1090-5.

20. Westhuizen van der L, Brown NL, Marasas WFO, Swanevelder S, Shephard GS. Sphinganine/sphingosine ratio in plasma and urine as a possible biomarker for fumonisin exposure in humans in rural areas of Africa. Food Chem Toxicol 1999;37:1153-8.

21. Qiu M, Liu X. Determination of sphinganine, sphingosine and $\mathrm{Sa} / \mathrm{So}$ ratio in urine of humans exposed to dietary fumonisin B. Food Addit Contam 2001;18:263-9.

22. Creppy EE, Chiarappa P, Baudrimont I, Borracci P, Moukha $S$, Carratù MR. Synergistic effects of fumonisin $B_{1}$ and ochratoxin $\mathrm{A}$ : are in vitro cytotoxicity data predictive of in vivo acute toxicity? Toxicology 2004;201:115-23. 
23. Šegvić Klarić M, Pepeljnjak S, Domijan A-M, Petrik J. Lipid peroxidation and glutathione levels in porcine kidney PK15 cells after individual and combined treatment with fumonisin $\mathrm{B}_{1}$, beauvericin and ochratoxin A. Basic Clin Pharmacol Toxicol 2007; 100:157-64.
24. Domijan A-M, Želježić D, Kopjar N, Peraica M. Standard and Fpg-modified comet assay in kidney cells of ochratoxin A- and fumonisin B1- treated rats. Toxicology 2006;222:539. 


\section{Sažetak}

\section{OKRATOKSIN A I OMJER SFINGANINA I SFINGOZINA U URINU STANOVNIKA S PODRUČJA} ENDEMSKE NEFROPATIJE U HRVATSKOJ

Najprihvatljivija teorija o etiologiji endemske nefropatije povezuje njezin nastanak s izloženošću nefrotoksičnim mikotoksinima. Dok se izloženost mikotoksinu okratoksinu A (OTA) može dokazati njegovim nalazom u biološkim uzorcima kao što su krv i urin, vrlo kratko zadržavanje fumonizina $B_{1}$ $\left(\mathrm{FB}_{1}\right)$ u organizmu to onemogućava. Na pokusnim je životinjama nađeno da je porast omjera koncentracija sfingolipida sfinganina i sfingozina $(\mathrm{Sa} / \mathrm{So}$ ) biološki pokazatelj izloženosti tom mikotoksinu. U ovom istraživanju mjerena je koncentracija OTA i omjer koncentracija Sa/So u urinu 45 stanovnika u endemskom selu Kaniža i 18 stanovnika u kontrolnom selu. Uzorci urina skupljeni su od istih osoba 2000. i 2005. godine. U obje godine učestalost uzoraka koji su sadržavali OTA bila je veća u Kaniži (43 \% i 18 \%) negoli u kontrolnom selu (28 \% i $6 \%$ ). Koncentracija OTA također je bila viša u urinima skupljenim u Kaniži negoli u kontrolnom selu. Koncentracija OTA u uzorcima skupljenim u Kaniži 2000. bila je viša nego u uzorcima iz 2005. ( $p<0.005$ ). Iako je u urinima iz obje godine omjer koncentracija Sa/So bio viši u Kaniži negoli u kontrolnom selu, razlika nije bila statistički značajna. Nije nađen nijedan uzorak skupljen u kontrolnom selu koji bi istodobno sadržavao mjerljivu koncentraciju OTA i omjer Sa/So veći od jedan. Za razliku od uzoraka iz kontrolnog sela, četiri uzorka skupljena u Kaniži u 2000. godini i jedan uzorak u 2005. godini upućivali su na istodobnu izloženost ovim mikotoksinima.

KLJUČCE RIJEČI: endemska nefropatija, fumonizin $B_{l}$, okratoksin A, sfingolipidi

\section{CORRESPONDING AUTHOR:}

Maja Peraica, MD, PhD

Institute for Medical Research and Occupational Health P. O. Box 291, HR-10001 Zagreb, Croatia

E-mail:mperaica@imi.hr 